\title{
Service design improvement in Ragunan Zoo using TRIZ methodology
}

\author{
Inaki Maulida Hakim ${ }^{1, *}$, Narpawandawi Kusuma ${ }^{1}$ and Teuku Yuri M. Zagloel ${ }^{1}$ \\ ${ }^{1}$ Department of Industrial Engineering, Faculty of Engineering, Universitas Indonesia, 16424 Depok, \\ Indonesia
}

\begin{abstract}
Indonesia is a country that has a great potential in tourism with its beautiful landscape and also the culture diversity. It makes government of Indonesia actively do development programs in the tourism sector to make tourism as one of the biggest contributor to Indonesia GDP. Ragunan Zoo has been selected to be the pilot project in cashless transaction at recreation places all over Indonesia. It has been applied since May 2016 but there still a lot of dissatisfaction from the visitor. So then, this research is trying to improve the service design in cashless transaction for ticket purchasing in Ragunan Zoo accordance with Ragunan visitor preferences to help successing government program. Researcher use Themequal to develop a questionnaire that has been distributed to 390 respondents. Result from questionnaire then processed using Fuzzy Gap Analysis and TRIZ method to get the possible solutions. Service Blueprint then used to illustrate the improvement of service design on ticket purchase at Ragunan Zoo based on the results.
\end{abstract}

\section{Introduction}

Supporting government program to make tourism as one of the biggest contributor to Indonesia GDP, Ragunan Zoo has been selected to be the pilot project for cashless transaction program. Then since May 2016 Ragunan has implemented the cashless transaction in ticket purchasing but there still dissatisfaction from the visitor. Based on the previous explanation, the goal is to proposed service design for entrance ticket purchasing in Ragunan Zoo that can meet customer preferences.

\section{Literatur Study}

\subsection{Themequal}

Service Quality (Servqual) is a method that can examine the gap between perceived service quality and expected service quality. Zeithaml, Berry and Parasuraman have conducted various studies on several types of services and successfully identified five dimensions of

\footnotetext{
* Corresponding author: inakimhakim@eng.ui.ac.id
} 
characteristics used by consumers in evaluating service quality [1]. But the fivedimensional SERVQUAL should be added a new dimension to be used in different conditions [2]. So then Tsang, Leee, Wong, \& Chong modified Servqual model to measure the service quality in theme park called Themequal model [3], as explained in Table 1.

Table 1. Six Dimensions of the Themequal Model.

\begin{tabular}{|c|l|}
\hline Dimension & Description \\
\hline Tangibles & Physical facilities, equipment, and appearance of personnel \\
\hline Reliability & To perform the promised service dependably and accurately \\
\hline Responsiveness & To help customers and provide prompt service \\
\hline Assurance & Courtesy knowledge, ability of employees to inspire trust and confidence \\
\hline Empathy & Caring, individualized attention the firm provides its customers \\
\hline Courtesy & $\begin{array}{l}\text { Politeness, respect, consideration, friendliness, and attitude of contact personnel, enabling } \\
\text { visitor to have a pleasant experience }\end{array}$ \\
\hline
\end{tabular}

\subsection{Fuzzy Gap Analysis}

The fuzzy set theory has been developed to solve the problem where the description of activity, observation and assessment is subjective, uncertain and not precise. Exact membership value is does not exist and usually its subjective in practice, and the most commonly used theory are fuzzy numbers, especially the Trapezoidal Fuzzy Number [4]. The mean values of $a, b$, and $c$ are Fuzzy values (to obtain a single representative value) using Aritmathic Mean formulated as follows:

$$
E V(T)=(a+2 b+c) / 4
$$

\subsection{TRIZ}

TRIZ (Theory of Inventive Problem Solving) is a systematic methodology of problembased problem solving with human-oriented [5]. The conceptual framework comprises of five main stages. Stage one and two analyze the original problems using cause and effect diagram, in order to provide insightful information for more detailed problem solving. Stage three structures the formulated problems into a typical TRIZ contradiction. Stage four uses TRIZ problem resolution tool which is contradiction matrix to generate the inventive principles solutions for service design. The last stage is evaluation of generated ideas. If solutions are still not found, the problem solving process must be iterated back to the first stage in order to redefine the original problems.

\subsection{Service Blueprint}

Service Blueprint is created to describe all the activities required for the service to function properly that is visible to the consumer, as well as that unseen by the consumer, it can help provide a clear roadmap for actual service delivery [6]. Service Blueprint is structured in five regions, there are physical evidence, customer action, front-liner, backend, and supporting process. 


\section{Research Methodology}

\subsection{Problem Analysis}

Questionnaire were distributed to respondents and 390 usable questionnaires result were returned. After processed by fuzzy gap analysis the result is shown in Table 2.

Table 2. Fuzzy Gap Analysis Results

\begin{tabular}{|c|c|c|c|c|c|c|c|c|c|c|}
\hline & \multirow{2}{*}{\multicolumn{4}{|c|}{ Importance }} & \multirow{2}{*}{\multicolumn{4}{|c|}{ Performance }} & \multirow{4}{*}{ Gap } \\
\hline & & & & & & & & & & \\
\hline & & \multicolumn{3}{|c|}{ TFN } & \multirow{2}{*}{ Real } & \multicolumn{3}{|c|}{ TFN } & \multirow{2}{*}{ Real } & \\
\hline & & Low & Crisp & Upp & & Low & Crisp & Upp & & \\
\hline \multicolumn{2}{|c|}{ ASSURANCE } & & & & 8.158 & & & & 6.974 & -1.185 \\
\hline $\begin{array}{l}\text { The behavior of the staff } \\
\text { gives confidence to the } \\
\text { visitors }\end{array}$ & Assurance1 & 5.949 & 8.449 & 9.462 & 8.077 & 4.434 & 6.896 & 8.798 & 6.756 & -1.321 \\
\hline $\begin{array}{l}\text { Visitor feel safe during } \\
\text { transaction }\end{array}$ & Assurance2 & 6.179 & 8.679 & 9.571 & 8.277 & 5.109 & 7.609 & 9.229 & 7.389 & -0.888 \\
\hline $\begin{array}{l}\text { The staff has sufficient } \\
\text { knowledge to answer } \\
\text { visitors' questions }\end{array}$ & Assurance3 & 5.955 & 8.455 & 9.615 & 8.120 & 4.447 & 6.909 & 8.837 & 6.775 & -1.345 \\
\hline \multicolumn{2}{|c|}{$\begin{array}{l}\text { COURTESY } \\
\end{array}$} & & & & 7.634 & & & & 6.602 & -1.032 \\
\hline $\begin{array}{l}\text { The visitors of HKDL } \\
\text { have a pleasant } \\
\text { experience }\end{array}$ & Courtesy1 & 4.872 & 7.308 & 8.821 & 7.077 & 4.094 & 6.568 & 8.586 & 6.454 & -0.623 \\
\hline $\begin{array}{l}\text { The staff members are } \\
\text { consistently polite }\end{array}$ & Courtesy2 & 6.071 & 8.558 & 9.577 & 8.191 & 4.454 & 6.889 & 8.766 & 6.750 & -1.441 \\
\hline \multicolumn{2}{|c|}{ EMPATHY } & & & & 7.583 & & & & 6.775 & -0.808 \\
\hline $\begin{array}{l}\text { The operating hours of } \\
\text { Ragunaan Zoo are } \\
\text { convenient for all visitors }\end{array}$ & Empathy 1 & 5.359 & 7.846 & 9.327 & 7.595 & 4.987 & 7.487 & 9.987 & 7.487 & -0.107 \\
\hline $\begin{array}{l}\text { Ragunan Zoo has staff } \\
\text { members who gives } \\
\text { visitors personal attention }\end{array}$ & Empathy2 & 5.359 & 7.859 & 9.199 & 7.569 & 4.139 & 6.587 & 8.548 & 6.465 & -1.104 \\
\hline $\begin{array}{l}\text { Ragunan Zoo has the } \\
\text { visitors' best interest at } \\
\text { heart }\end{array}$ & Empathy3 & 5.353 & 7.795 & 9.160 & 7.526 & 4.338 & 6.780 & 8.625 & 6.631 & -0.895 \\
\hline $\begin{array}{l}\text { Ragunan Zoo can give } \\
\text { visitors individual } \\
\text { attention }\end{array}$ & Empathy4 & 5.160 & 7.660 & 9.122 & 7.401 & 4.229 & 6.677 & 8.451 & 6.509 & -0.892 \\
\hline $\begin{array}{l}\text { The staff of Ragunan Zoo } \\
\text { can understand the } \\
\text { specific needs of visitors }\end{array}$ & Empathy5 & 5.647 & 8.135 & 9.391 & 7.827 & 4.486 & 6.947 & 8.760 & 6.785 & -1.042 \\
\hline \multicolumn{2}{|c|}{ RELIABILITY } & & & & 8.048 & & & & 6.810 & -1.238 \\
\hline $\begin{array}{l}\text { When a visitor has a } \\
\text { problem, the staff of the } \\
\text { Ragunan Zoo will help } \\
\text { the visitor to solve the } \\
\text { problem }\end{array}$ & Reliability1 & 6.224 & 8.724 & 9.603 & 8.319 & 4.434 & 6.902 & 8.824 & 6.766 & -1.553 \\
\hline $\begin{array}{l}\text { All the performance and } \\
\text { activities of Ragunan Zoo } \\
\text { start on time }\end{array}$ & Reliability2 & 5.923 & 8.423 & 9.571 & 8.085 & 4.698 & 7.172 & 8.972 & 7.004 & -1.081 \\
\hline $\begin{array}{l}\text { The facilities in the } \\
\text { Ragunan are safe }\end{array}$ & Reliability3 & 6.006 & 8.506 & 9.487 & 8.127 & 4.994 & 7.468 & 9.055 & 7.246 & -0.880 \\
\hline $\begin{array}{l}\text { Ragunan can meet the } \\
\text { commitment they have } \\
\text { made in their } \\
\text { advertisements and } \\
\text { brochures }\end{array}$ & Reliability4 & 6.179 & 8.679 & 9.571 & 8.277 & 5.109 & 7.571 & 9.087 & 7.335 & -0.943 \\
\hline $\begin{array}{l}\text { The facilities within the } \\
\text { Ragunana Zoo are reliable }\end{array}$ & Reliability5 & 5.571 & 8.045 & 9.256 & 7.729 & 3.798 & 6.234 & 8.380 & 6.162 & -1.568 \\
\hline $\begin{array}{l}\text { Ragunan Zoo can } \\
\text { accurately perform the } \\
\text { service }\end{array}$ & Reliability6 & 5.590 & 8.077 & 9.263 & 7.752 & 4.042 & 6.485 & 8.393 & 6.351 & -1.400 \\
\hline \multicolumn{2}{|c|}{ RESPONSIVENESS } & & & & 7.948 & & & & 6.655 & -1.292 \\
\hline $\begin{array}{l}\text { The staffs are never too } \\
\text { busy to respond visitors' } \\
\text { requests }\end{array}$ & Responsiveness 1 & 5.577 & 8.064 & 9.205 & 7.728 & 4.113 & 6.575 & 8.535 & 6.449 & -1.278 \\
\hline
\end{tabular}




\begin{tabular}{|l|l|l|l|l|l|l|l|l|l|l|}
$\begin{array}{l}\text { The staff can tell visitors } \\
\text { exactly when } \\
\text { service/performance will } \\
\text { be performed }\end{array}$ & Responsiveness2 & 5.801 & 8.288 & 9.449 & 7.957 & 4.460 & 6.960 & 8.843 & 6.806 & -1.151 \\
\hline $\begin{array}{l}\text { The staffs are willing to } \\
\text { help visitors }\end{array}$ & Responsiveness3 & 5.788 & 8.276 & 9.410 & 7.938 & 4.473 & 6.960 & 8.843 & 6.809 & -1.128 \\
\hline $\begin{array}{l}\text { The visitors can obtain } \\
\text { information from the staff } \\
\text { easily }\end{array}$ & Responsiveness4 & 6.135 & 8.622 & 9.571 & 8.237 & 4.447 & 6.934 & 8.785 & 6.775 & -1.462 \\
\hline $\begin{array}{l}\text { The visitor can obtain } \\
\text { information from the staff } \\
\text { easily }\end{array}$ & Responsiveness5 & 5.712 & 8.179 & 9.256 & 7.832 & 3.901 & 6.350 & 8.310 & 6.228 & -1.604 \\
\hline $\begin{array}{l}\text { The visitors of Ragunan } \\
\text { Zoo can access the staff } \\
\text { easily }\end{array}$ & Responsiveness6 & 5.853 & 8.353 & 9.423 & 7.995 & 4.512 & 7.012 & 8.927 & 6.865 & -1.130 \\
\hline
\end{tabular}

Table 3. Fuzzy Gap Analysis Results (continue)

\begin{tabular}{|c|c|c|c|c|c|c|c|c|c|c|}
\hline & & \multicolumn{4}{|c|}{ Importance } & \multicolumn{4}{|c|}{ Performance } & \multirow{3}{*}{ Gap } \\
\hline & & \multicolumn{3}{|c|}{ TFN } & \multirow{2}{*}{ Real } & \multicolumn{3}{|c|}{ TFN } & \multirow{2}{*}{ Real } & \\
\hline & & Low & Crisp & Upp & & Low & Crisp & Upp & & \\
\hline \multicolumn{2}{|l|}{ TANGIBLES } & & & & 7.657 & & & & 6.431 & -1.226 \\
\hline $\begin{array}{l}\text { The facilities within } \\
\text { Ragunan Zoo have a } \\
\text { modern outlook }\end{array}$ & Tangibles1 & 5.192 & 7.679 & 9.179 & 7.433 & 4.460 & 6.934 & 8.817 & 6.787 & -0.646 \\
\hline $\begin{array}{l}\text { The staff of Ragunan Zoo } \\
\text { have neat appearances }\end{array}$ & Tangibles2 & 5.891 & 8.391 & 9.423 & 8.024 & 4.152 & 6.613 & 8.586 & 6.491 & -1.533 \\
\hline $\begin{array}{l}\text { The facilities within the } \\
\text { Ragunan zoo are visually } \\
\text { appealing }\end{array}$ & Tangibles3 & 5.301 & 7.776 & 9.090 & 7.486 & 3.515 & 5.887 & 8.046 & 5.834 & -1.652 \\
\hline $\begin{array}{l}\text { The interpretation } \\
\text { materials-e.g., leaflets, } \\
\text { signpost, and map-within } \\
\text { the Ragunan Zoo are } \\
\text { visually appealing }\end{array}$ & Tangibles 4 & 5.442 & 7.942 & 9.417 & 7.686 & 4.261 & 6.729 & 8.734 & 6.613 & -1.073 \\
\hline
\end{tabular}

\subsection{Problem Modelling \& Formulation}

The cause effect diagram was built through a deep interview with the experts using data from the fuzzy gap analysis result (Figure 3) to understand the relationship among the function in sales and service Office.

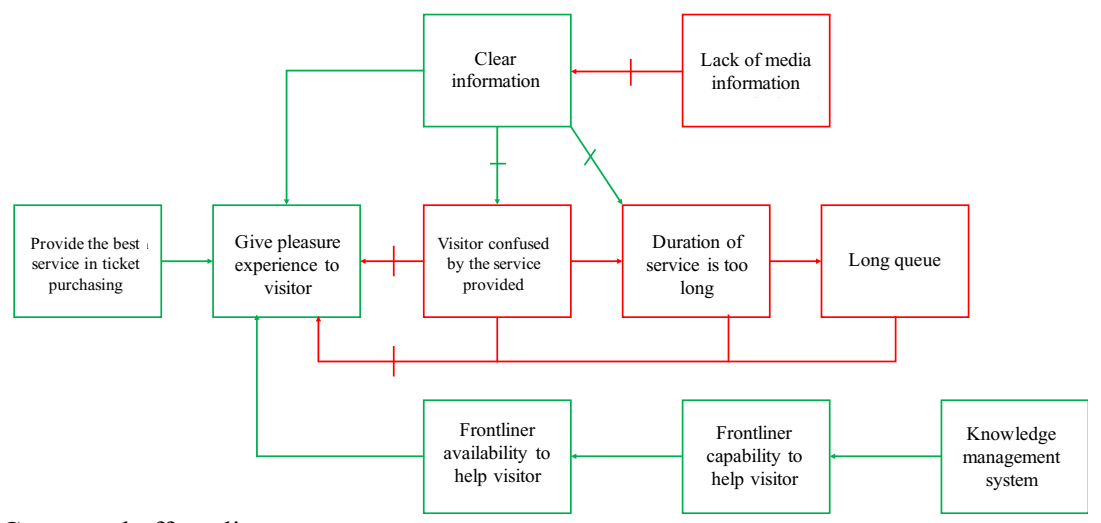

Fig. 1. Cause and effect diagram

From Figure 1 we can see the problem performed in the ticketing purchasing service in Ragunan Zoo. It can lead to the problem statement as formulated in Table 4. 
Table 4. Problem Statements

\begin{tabular}{|c|l|}
\hline No & \multicolumn{1}{|c|}{ Problem Statement } \\
\hline 1 & $\begin{array}{l}\text { Find a way to improve effectiveness of ticket purchasing service that provide a pleasure } \\
\text { experience }\end{array}$ \\
\hline 2 & $\begin{array}{l}\text { Find an alternative way to provide service that give a pleasure experience with a clear } \\
\text { information }\end{array}$ \\
\hline 3 & $\begin{array}{l}\text { Find an alternative way to make visitor understand the ticket purchasing system without } \\
\text { information media }\end{array}$ \\
\hline 4 & Find a way to improve media information to help visitors \\
\hline 5 & Find a way to provide a pleasure experience at ticket purchasing by not generating long queue \\
\hline 6 & Find a way to shorten the duration of ticket purchasing service in TMR \\
\hline 7 & Find a way to take advantage of long queues \\
\hline 8 & Find an alternative way to make visitors not confused with the ticket purchasing system \\
\hline 9 & $\begin{array}{l}\text { Find an alternatives way to provide ticket purchasing service without requiring a lot of front- } \\
\text { liner }\end{array}$ \\
\hline 10 & Find a way to solve dissatisfaction caused by lack of competencies from front-liner \\
\hline 11 & Find an alternative way to increase front-liner competencies \\
\hline 12 & Find another benefit from knowledge management system \\
\hline
\end{tabular}

\subsection{Contradiction Analysis}

After finding the problem statement then we do analysis using one of the most used TRIZ tools which is contradiction matrix. To do the contradiction analysis we should mapping the improving parameter and worsening parameter based on the problem statement to get the TRIZ inventive principles that will be proposed. TRIZ inventive principles from this research is listed in Table 5.

Table 5. TRIZ Inventive Principles

\begin{tabular}{|l|l|l|}
\hline \multicolumn{2}{|c|}{ TRIZ Inventive Principle } & Definition \\
\hline 1 & Segmentation & Eliminates low value processes and uses high value processes \\
\hline 2 & Taking out & Customize or customize to provide different features in different environments \\
\hline 3 & Local Quality & Changing the process to be different from the general process \\
\hline 4 & Asymmetry & Combine services to create new services \\
\hline 5 & Merging & Provide multifunctional services \\
\hline 6 & Universality & Avoid heavy risks by eliminating them \\
\hline 8 & Anti-weight & $\begin{array}{l}\text { Conducting activities before service is provided to make the service faster and } \\
\text { easier }\end{array}$ \\
\hline 10 & Preliminary action & Map the bad effects by preparing the worst scenarios that can occur \\
\hline 11 & $\begin{array}{l}\text { Beforehand } \\
\text { cushioning }\end{array}$ & Identify necessary changes to a service \\
\hline 14 & Spheroidality & Make the service more flexible \\
\hline 15 & Dynamics & Services given at certain times / periods are not done continuously \\
\hline 19 & Periodic action & Turning bad activity into a beneficial activity \\
\hline 22 & $\begin{array}{l}\text { Convert harm into } \\
\text { benefit }\end{array}$ & Make a result an input to improve the service \\
\hline 23 & Feedback & $\begin{array}{l}\text { Recommend using outside personnel as part of the service to perform additional } \\
\text { functions }\end{array}$ \\
\hline 24 & Intermediary & Duplicate other processes so that the cost used is cheaper \\
\hline 26 & Copying & Replacing the service system becomes something acceptable to the senses \\
\hline 28 & Mechanics substituion & $\begin{array}{l}\text { Eliminates problematic processes to improve service quality, reduce costs, and } \\
\text { increase reliability }\end{array}$ \\
\hline
\end{tabular}




\begin{tabular}{|c|l|l|}
\hline 30 & $\begin{array}{l}\text { Flexible shells and } \\
\text { thin films }\end{array}$ & $\begin{array}{l}\text { Eliminates problematic processes to improve service quality, reduce costs, and } \\
\text { increase reliability }\end{array}$ \\
\hline 32 & Color changes & $\begin{array}{l}\text { Eliminates a number of functions from the service or reuses a number of } \\
\text { functions of the service }\end{array}$ \\
\hline 34 & $\begin{array}{l}\text { Discarding and } \\
\text { recovering }\end{array}$ & Changed the service resources to improve the experience and value for visitors \\
\hline 35 & Parameter changes & Create new services and add value to the service \\
\hline 36 & Phase transitions & Adding services with stimulation can speed up the service process \\
\hline 38 & Strong oxidants & Creating services that can be used by different people, non-homogeneous \\
\hline 40 & $\begin{array}{l}\text { Composite material } \\
\text { films }\end{array}$ & $\begin{array}{l}\text { Membuat pelayanan yang dapat digunakan oleh berbagai macam orang yang } \\
\text { berbeda, non-homogen }\end{array}$ \\
\hline
\end{tabular}

\section{Result and Discussion}

The questionnaire in this research based on previous literature studies which is Themqual, a service quality research in Hongkong Disneyland. Themqual is the modified Servqual to perform service quality analysis at theme park. In that literature, Nelson, Louisa, Alan, and Rita Chong adds an important dimension which is courtesy. But the results from this research in Ragunan Zoo shown that the level of reliability and validity from courtesy dimension is quite low compared to other dimensions. Due to this limitation, future research may verify the the Themqual model so then it can provide a higher level of reliability and validity.

\section{Conclusion}

After get the possible improvement are then summarized into new service blueprint. Then researcher make two kind of purchasing, the first one is on the spot ticket purchasing service that uses solutions such as maximizing the use of speakers, updating the counter and information boards to make them more visible, separating services at each counter based on services, updating information boards to make it more understandable, expanding cooperation with outsources to conduct transactions other than JakCard, and also separate vehicle parking payments with ticket purchasing. Then the other purchasing method is online purchasing service. Where visitors make reservation through the website which will then provide them with booking code that will be used to print the ticket through a selfservice machine. The online purchase service answers some solution points such as using self-service machines, counter separation, creating online services, expanding Ragunan's cooperation with outsources.

This research received funding from the PITTA Grant at Universitas Indonesia

\section{References}

1. Parasuraman. A, VA. Zeithaml, LL. Berry, Jour. of Mark., 49, (1985)

2. JM. Carman, Jour. of Retail., (1990)

3. N. K. F. Tsang, L. Y. S. Lee, A. Wong, R. Chong, Jour. of TTM, 29(5), 416-429. (2012)

4. L.K. Chan, A. NG. Kau, M.L. Wu, Int. Jour. of Prod. Research, 37, (1999)

5. S. Savransky, CRC Press., (2000)

6. M. Stickdorn, J. Schneider, John Wiley \& Sons, Inc. (2011) 